\title{
FEATURES OF TRAINING GUARANTEES OF EDUCATIONAL PROGRAMS FOR ACCREDITATION: THE UKRAINIAN EXPERIENCE
}

\section{Anna Helesh ${ }^{1}$}

DOI: https://doi.org/10.30525/978-9934-26-002-5-4

According to regulations «On Accreditation of Study in Higher Education» [2], developed by the National Agency for Higher Education Quality Assurance, approved in 2019, the guarantor implements and ensuring the quality of its educational program, including training information on selfassessment of the educational program during the accreditation examination of this program by the institution of higher education.

Having studied some features of the organizational activities of guarantors of educational programs and their functional responsibilities for the development and implementation of educational programs, ensuring and quality control of higher education for this program [1, p. 255-257], the author's focus is on defining the responsibilities of guarantors during the accreditation examinations of their educational programs.

In view of this, the need to prepare guarantors of educational programs at the stage of preparation for the accreditation examinations of their educational programs becomes relevant. Therefore, the author proposes to train the guarantors of educational programs to pass accreditation examinations through introducing a special training module in the program of advanced training of scientific and pedagogical staff of higher education institutions.

Today there is a separate experience of preparation of guarantors of educational programs for passing of accreditation examinations of their educational programs. Thus, in 2020 the author developed and implemented in the training program «Formation and development of professional and personal competencies of researchers and teachers» of the National University «Lviv Polytechnic» [3] training module «Accreditation examination and features of quality assessment of educational programs».

The training module is designed for 30 hours / 1 ECTS credit, taking into account independent (extracurricular) work. During lectures and practical classes we use various forms and methods of teaching, in particular: presentations, discussions, team work; methods of organization and selforganization of educational and cognitive activities (heuristic conversation, demonstration, illustration, independent observation, practical teaching

\footnotetext{
${ }^{1}$ National University «Lviv Polytechnic», Ukraine
} 
methods); methods of formation of cognitive interests (method of creating a situation of novelty of educational material, method of reliance on life experience, method of didactic cognitive games, method of creating a sense of success in learning). The final stage of the training module is a course work on «Information about self-assessment of the educational program», the feature of which is that it is prepared by the guarantor of the educational program together with other students of the graduating department of this educational program. Because of advanced training, students receive a certificate containing the name of the training module, program learning outcomes and the number of hours (ECTS credits).

The material of the training module is systematized and organized by topics so, as to form students' knowledge of the theory and practice of accreditation examinations and features of quality assessment of educational programs, and skills and abilities to apply them in the process of accreditation examinations of educational programs.

During October 2020, for the first time, the training took place in this module at the National University «Lviv Polytechnic». Guarantors of three educational and professional master's programs and three or four scientific and pedagogical employees of the graduating departments of these educational programs were included in the category of students. The author has completed educational and methodological materials, in particular, developed a training form of internal selfassessment of educational programs, which participants work with during classes. It should be noted, that students have already had the opportunity to apply the acquired knowledge, skills and abilities in practice during the accreditation examinations of their educational programs.

In order to determine the level of usefulness of the training module for its participants, as well as to provide feedback, the author developed a questionnaire and conducted a survey among the participants of the training module. The survey was conducted in the form of an online survey with using the public resource Google Forms, subject to anonymity. The survey was attended by 11 participants (a group of students, who were trained in October 2020), from among the guarantors of educational programs and other participants in the educational process.

Thus, according to the obtained data, it was determined that in general the training module met the expectations of the participants (Figure 1). After all, $90.9 \%$ of respondents confirmed that the training module fully met their expectations. As a positive fact, we can note that none of the respondents believes that the training module did not meet the expectations of students.

The following questions involved determining the level of usefulness of the training module for guarantors of educational programs in the process of preparation for accreditation examinations of their educational programs, as 
well as other participants in the educational process in the process of preparation for accreditation examinations of educational programs (Figure 2, 3).

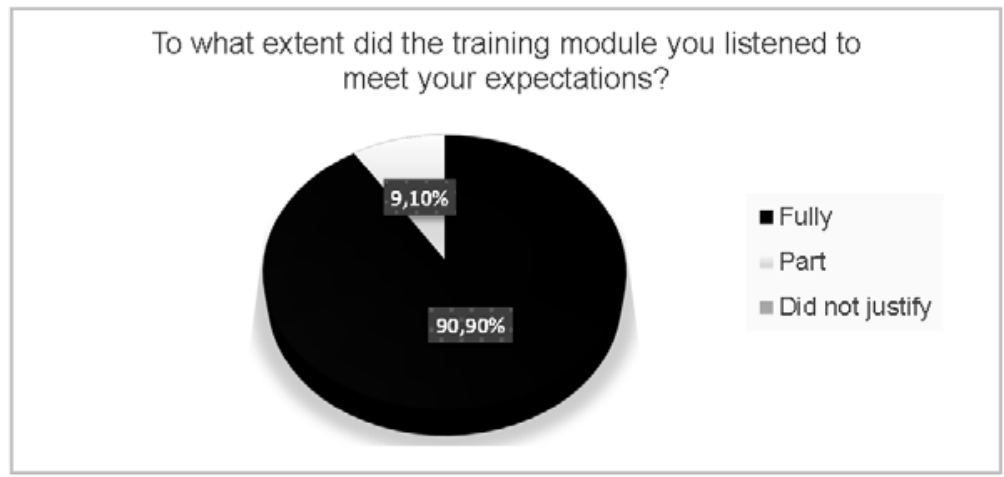

Figure 1. Compliance of the training module with the expectations of its participants

In your opinion, how useful is the training module for guarantors of educational programs in the process of preparation for accreditation examinations of educational programs?

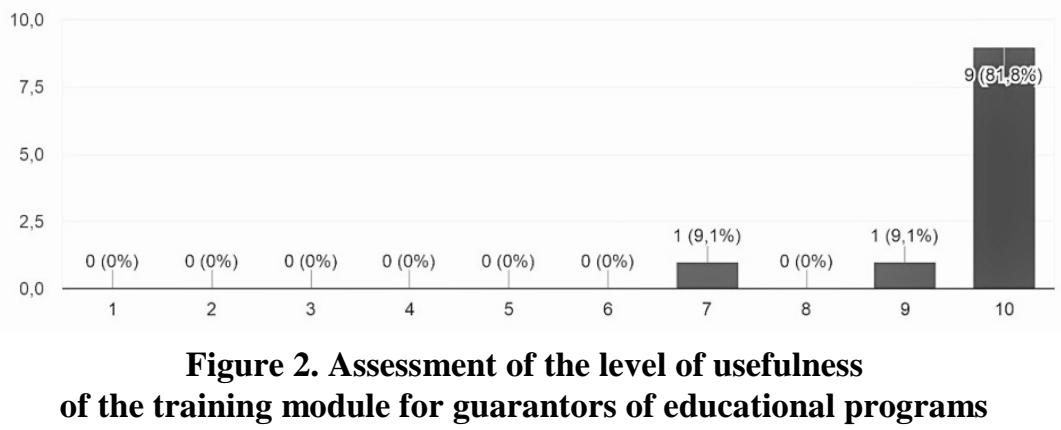

Thus, $81.8 \%$ of participants rated the usefulness of the initial module at 10 points (very useful) for guarantors of educational programs. From fig. 3. it is seen that the training module proposed by the author is useful not only for the guarantors of educational programs, but also for other participants in the educational process. The level of usefulness varies from 7 to 10 points, which indicates the effectiveness of the training module and the need for its further implementation. 
In your opinion, how useful is the training module for other participants in the educational process in the process of preparation for accreditation examinations of educational programs?

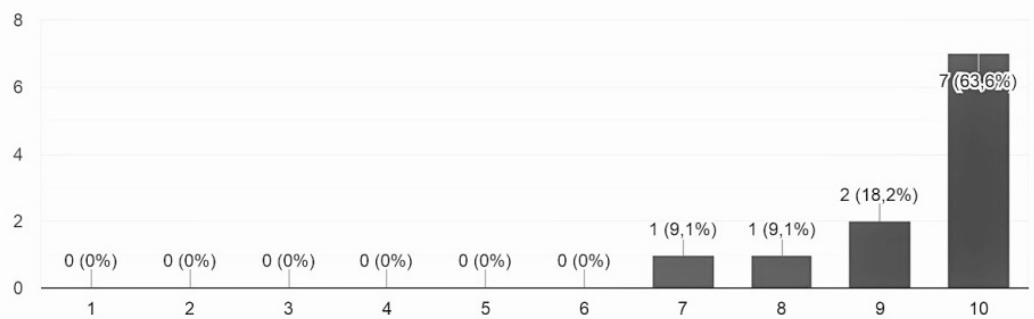

Figure 3. Assessment of the level of usefulness of the training module for other participants in the educational process

Thus, the author proves that this training module is relevant and necessary both for guarantors of educational programs and for other participants in the educational process in the process of preparation for accreditation examinations of educational programs of Ukrainian universities. In future, author plan to publish the results of the study in full. On the basis is to summarize the proposals and recommendations of the participants on the content of the training module «Accreditation examination and features of quality assessment of educational programs».

\section{References:}

1. Helesh, A.V. (2020). Dejaki osoblyvosti orghanizacijnoji dijaljnosti gharanta osvitnjoji proghramy. Theory, science and practice: Abstracts of III International Scientific and Practical Conference (Tokio, Japan).

2. Pro akredytaciju osvitnikh proghram, za jakymy zdijsnjujetjsja pidghotovka zdobuvachiv vyshhoji osvity: Polozhennja NAZJaVO vid 11.07.2019 r. № 977. Available at: https://zakon.rada.gov.ua/laws/show/z0880-19\#Text

3. Formuvannja ta rozvytok profesijno-osobystisnykh kompetentnostej naukovopedaghoghichnykh pracivnykiv: Proghrama pidvyshhennja kvalifikaciji naukovopedaghoghichnykh pracivnykiv vid 28.08 .2020 r. U Available at: https://lpnu.ua/ sites/default/files/attach/2020/16510/zavirena_profesiyna_programa_pk_npp_nulp.pdf 